\title{
Meio de cultura semi-seletivo para deteç̧ão de Curtobacterium flaccumfaciens pv. flaccumfaciens em solo e sementes de feijoeiro.
}

\author{
Franklin Behlau ${ }^{1}$, Liliane Moreira Nunes ${ }^{2} \&$ Rui Pereira Leite $\mathrm{Jr}^{2}$
}

\begin{abstract}
${ }^{1}$ Departamento de Entomologia, Fitopatologia e Zoologia Agrícola, Escola Superior de Agricultura "Luiz de Queiroz", Esalq/USP, CP 09, CEP 13418-900, Piracicaba, SP, e-mail: franklinbehlau@yahoo.com.br. ${ }^{2}$ Laboratório de Bacteriologia e Virologia, Área de Proteção de Plantas, Instituto Agronômico do Paraná, IAPAR, CP 481, CEP 86001-970, Londrina, PR, e-mail: ruileite@iapar.br.

Autor para correspondência: Rui Pereira Leite Jr.

Data de chegada: 12/11/2004. Aceito para publicação em: 17/10/2005.
\end{abstract}

\begin{abstract}
Behlau, F., Nunes, L.M., Leite Jr., R.P. Semi-selective medium for detection of Curtobacterium flaccumfaciens pv. flaccumfaciens in soil and on bean seeds. Summa Phytopathologica, v.32, n.4, p.394-396, 2006.

Bacterial wilt, caused by Curtobacterium flaccumfaciens pv. flaccumfaciens, is an important disease for bean (Phaseolus vulgaris L.) production in Southern Brazil. The use of contamined seeds is the major way to spread the bacterium. Although the occurrence of this disease in Brazil is recent, the seedborne bacterium hase been disseminated to most of the bean producing areas. The objective of this study was to adjust the CNS (Corynebacterium Nebraskense Selective Medium) to recover and detect the bacterium in infected

soil as well as in bean seeds. Suspensions obtained from washing infected soil and bean seeds contamined by the bacterium were plated onto modified CNS medium. The modified CNS was efficient to recover the bacterium from both contaminated soil and bean seeds. The CNS established medium differed from the original by reducing the concentration of polymyxin $B$ sulfate to $16 \mathrm{mg} / 1$, excluding cyclohexamide and replacing Daconil 2787-F fungicide $(530 \mathrm{mg} / \mathrm{ml}$ chlorothalonil) with Dacostar $500(500 \mathrm{mg} / \mathrm{ml}$ chlorothalonil).
\end{abstract}

Keywords: Phaseolus vulgaris, bacterial wilt, seed pathology, survival.

\section{RESUMO}

Behlau, F., Nunes, L.M., Leite Jr., R.P. . Meio de cultura semi-seletivo para detecção de Curtobacterium flaccumfaciens pv. flaccumfaciens em solo e sementes de feijoeiro. Summa Phytopathologica, v.32, n.4, p.394-396, 2006.

A murcha-de-curtobacterium, causada pela bactéria Curtobacterium flaccumfaciens pv. flaccumfaciens (Cff), é um importante problema para o cultivo de feijão (Phaseolus vulgaris L.) na região Centro-Sul do Brasil. A principal forma de disseminação da bactéria é por sementes contaminadas. Embora a ocorrência desta doença seja relativamente recente no Brasil, Cff tem sido disseminado rapidamente nas regiões produtoras de feijão do país. Este trabalho teve como objetivo ajustar o meio de cultura CNS (Corynebacterium Nebraskense Selective Medium) para recuperação e detecção de Cff em solo e sementes de feijoeiro.
Suspensões provenientes da lavagem de amostras de solo e sementes contaminadas pela bactéria foram plaqueadas no meio de cultura CNS modificado. Os ajustes realizados no meio de cultura possibilitaram a recuperação eficiente de Cff presente em solo e sementes contaminadas. As modificações estabelecidas para o meio CNS foram a redução da concentração de sulfato de polimixina para $16 \mathrm{mg} / \mathrm{l}$, exclusão do componente ciclohexamida e substituição do fungicida Daconil 2787-F $(530 \mathrm{mg} / \mathrm{ml}$ de chlorothalonil) pelo Dacostar $500(500 \mathrm{mg} / \mathrm{ml} \mathrm{de}$ chlorothalonil).
A murcha-de-curtobacterium, causada por Curtobacterium flaccumfaciens pv. flaccumfaciens (Hedges) Collins \& Jones (Cff), é uma importante doença para a cultura do feijoeiro (Phaseolus vulgaris L.) (5). Essa doença foi constatada pela primeira vez no Brasil em 1995, no Estado de São Paulo (4). Recentemente, a presença da doença também foi reportada nos Estados do Paraná e Santa Catarina (3).

Os principais sintomas da murcha-de-curtobacterium são encharcamento e flacidez dos folíolos durante períodos quentes e secos, que normalmente progridem para a formação de lesões amareladas e necróticas nas folhas. As sementes de feijoeiro infectadas normalmente apresentam descoloração e enrugamento. Danos mais severos causados pela murcha-de-curtobacterium ocorrem quando da infecção nos primeiros estágios de desenvolvimento do feijoeiro. As plantas novas infectadas normalmente não se desenvolvem ou morrem (2).

A bactéria Cffé transmitida por sementes, que podem ser infectadas externa ou internamente, a partir da infecção sistêmica da planta. 
Sementes infectadas são o principal meio de disseminação do patógeno a longas distâncias (2).

O presente trabalho teve como objetivo principal realizar adaptações no meio de cultura CNS (Corynebacterium Nebraskense Selective Medium) $(1,6)$ com a finalidade de recuperar e detectar Cff em solo e sementes contaminadas.

Desta forma, o meio de cultura CNS, semi-seletivo para determinadas bactérias corineformes $(1,6)$, foi modificado com base em estudos do crescimento de Cff em diferentes variações da composição do meio de cultura. Cabe salientar que no meio CNS elaborado conforme o protocolo original $(1,6)$ não foi possível constatar o crescimento de isolados de Cff obtidos no Brasil. Após modificações no meio CNS, suspensões de Cff obtidas de solo e sementes contaminadas foram plaqueadas com a finalidade de testar a eficiência do meio CNS - modificado para a detecção da bactéria.

A seletividade do meio CNS - modificado foi avaliada utilizandose suspensões de bactérias fitopatogênicas Gram-positivas, como Cff e Clavibacter michiganensis subsp. michiganensis e também de bactérias fitopatogênicas Gram-negativas, como Xanthomonas axonopodis pv. citri, Pantoea agglomerans (sin. Erwinia herbicola), Ralstonia solanacearum, Pseudomonas syringae pv. syringae e Agrobacterium tumefaciens. As suspensões bacterianas, ajustadas em espectrofotômetro a $600 \mathrm{~nm}$, foram plaqueadas no meio de cultura nas concentrações aproximadas de $10^{3}, 10^{4}$ e $10^{5} \mathrm{UFC} \mathrm{ml}^{-1}$.

Solo contaminado por Cff foi obtido a partir da incorporação de plantas de feijoeiro do cultivar IAC Carioca, cultivadas em casa de vegetação e inoculadas com a bactéria Cff sete dias após a semeadura. As plantas foram incorporadas ao solo quatro semanas após a inoculação. Amostras de $10 \mathrm{~g}$ de solo foram coletadas e colocadas em $80 \mathrm{ml}$ de água de torneira autoclavada, logo após a incorporação das plantas de feijoeiro doentes ao solo. As amostras de solo foram mantidas sob agitação a $26^{\circ} \mathrm{C}$, por uma hora e meia. Após agitação, foi feito plaqueamento de $100 \mu \mathrm{l}$ das diluições de $10^{-1}, 10^{-2}$ e $10^{-3}$, em relação à suspensão inicial, em meio CNS - modificado.

A eficiência do meio CNS - modificado na recuperação de Cff presente em sementes foi determinada utilizando-se $10 \mathrm{~g}$ de sementes obtidas de feijoeiro 'IAC Carioca', inoculado com a bactéria em casa de vegetação. As sementes foram colocadas em $20 \mathrm{ml}$ de água de torneira autoclavada, permanecendo sob agitação a $26^{\circ} \mathrm{C}$ por uma hora e meia. Após agitação, $100 \mu 1$ das diluições $10^{-1}, 10^{-2}$ e $10^{-3}$ em relação à suspensão inicial foram plaqueados em meio CNS - modificado.

O meio de cultura não seletivo Nutriente Ágar (NA) (6) foi utilizado para determinar a população bacteriana total presente nas diferentes amostras examinadas neste estudo. Amostras de solo e sementes não contaminadas por Cff foram utilizadas como controle negativo.

Modificações foram estabelecidas no meio de cultura CNS com o objetivo de obter crescimento seletivo de Cff. A quantidade de sulfato de polimixina $B$ foi reduzida para $16 \mathrm{mg} / 1$; o componente ciclohexamida foi excluído, pois mesmo na sua ausência foi obtida com sucesso a supressão do crescimento de microrganismos contaminantes. O fungicida Daconil 2787-F (530 mg/ml de chlorothalonil) foi substituído pelo Dacostar $500(500 \mathrm{mg} / \mathrm{ml}$ de chlorothalonil).

$\mathrm{O}$ meio CNS - modificado, semi-seletivo para Cff, foi preparado pela adição dos seguintes componentes para um volume final de 1 litro de meio de cultura: $8,0 \mathrm{~g}$ de caldo nutriente; $2,0 \mathrm{~g}$ de extrato de levedura; $2,0 \mathrm{~g}$ de $\mathrm{K}_{2} \mathrm{HPO}_{4} ; 0,5 \mathrm{~g}$ de $\mathrm{KH}_{2} \mathrm{PO}_{4} ; 10,0 \mathrm{~g}$ de LiCl; $15,0 \mathrm{~g}$ de ágar; 5,0 g de glicose e $124 \mathrm{mg}$ de sulfato de magnésio anidro. As soluções de glicose e sulfato de magnésio foram autoclavadas separadamente e adicionadas ao meio esterilizado. Após autoclavagem e resfriamento do meio a aproximadamente $50{ }^{\circ} \mathrm{C}$, foram adicionados
$25 \mathrm{mg}$ de ácido nalidíxico (solubilizado em 0,1 M NaOH, $10 \mathrm{mg} / \mathrm{ml}$; Acros, Geel, Bélgica); $16 \mathrm{mg}$ de sulfato de polimixina $B$ (7740 unidades USP/mg, $10 \mathrm{mg} / \mathrm{ml}$; Gibco BRL, Grand Island, NY) e 1,2 ml do fungicida Dacostar 500 (chlorothalonil 500 mg/ml; Hokko do Brasil, São Paulo, $\mathrm{SP})$. Antes de serem adicionadas ao meio, estas soluções foram preparadas separadamente e esterilizadas por filtração.

O meio CNS - modificado apresentou alta especificidade para Cff, não tendo sido observado crescimento de isolados dos outros gêneros de bactérias fitopatogênicas testados. Além disso, o meio CNS modificado apresentou eficiência na recuperação de Cff de solo e sementes contaminadas pelo patógeno. Entretanto, foi observado, em número reduzido, o crescimento de outras bactérias presentes em amostras de solo nas placas de meio CNS - modificado. Apesar disto, a seletividade do meio CNS - modificado para Cff possibilitou a identificação e o isolamento desta bactéria mesmo na presença de outros microrganismos. Em contraste, no meio NA não foi possível identificar colônias de Cff devido à presença de grande número de colônias de outros microrganismos (Fig. 1). Além disso, com base em outros estudos, a população de Cff recuperada no meio CNS modificado a partir de suspensões puras de Cff foi semelhante àquela observada no meio não seletivo NA (dados não apresentados).
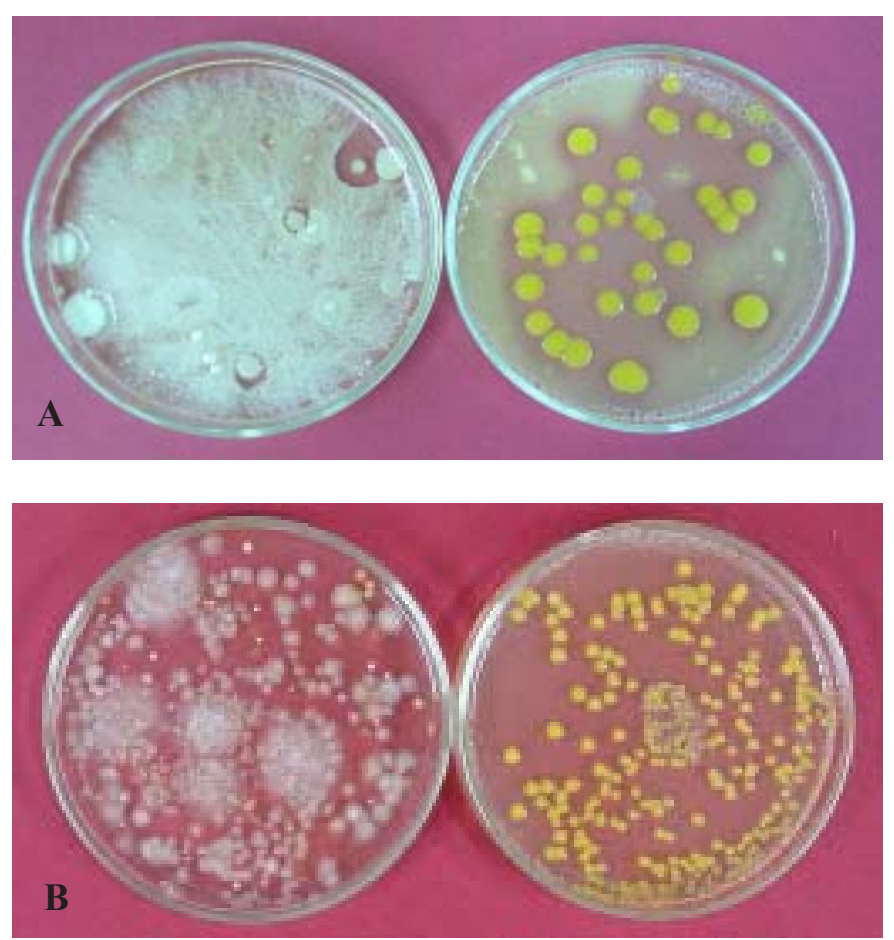

Figura 1. Crescimento comparativo de Cff (colônias amarelas) e outros microrganismos presentes em amostras de solo (A) e sementes de feijoeiro (B) contaminadas por Cff, em meio NA (à esquerda) e CNS modificado (à direita), na diluição de $10^{-3}$.

Os resultados obtidos no presente estudo mostraram a eficiência do meio CNS - modificado na recuperação de Cff de amostras de solo e sementes de feijoeiro contaminadas por esta bactéria. O meio CNS - modificado pode ser utilizado como ferramenta em estudos epidemiológicos e ecológicos da bactéria, assim como em análises fitossanitárias de sementes de feijoeiro. 


\section{REFERÊNCIAS BIBLIOGRÁFICAS}

1. Gross, D.C.; Vidaver, A.K. A selective medium for isolation of Corynebacterium nebraskense from soil and plant parts. Phytopathology, St. Paul, v.69, p.82-87, 1979.

2. Hedges, F. Bacterial wilt of beans (Bacterium flaccumfaciens Hedges), including comparisons with Bacterium phaseoli. Phytopathology, St. Paul, v.16, p.1-22, 1926.

3. Leite Junior., R.P.; Meneguim, L.; Behlau, F.; Rodrigues, S.R.; Bianchini, A. Ocorrência de Curtobacterium flaccumfaciens subsp. flaccumfaciens em feijoeiro no Paraná e Santa Catarina. Fitopatologia
Brasileira, Brasília, v.26, supl., p. 303-304, 2001. (Resumo).

4. Maringoni, A.C.; Rosa, E.F. Ocorrência de Curtobacterium flaccumfaciens pv. flaccumfaciens em feijoeiro no Estado de São Paulo. Summa Phytopathologica, Botucatu, v.23, p.160-162, 1997.

5. Saettler, A.W. Diseases caused by bacteria. In: Hall, R. Compendium of bean diseases. St. Paul: The American Phytopathological Society, 1991. p.29-32

6. Schaad, N.W.; Jones, J.B.; Chun, W. Laboratory guide for identification of plant pathogenic bacteria. 3rd. ed. St. Paul: APS Press, 2001. 221p. 